\title{
負荷変動に対するロバスト性を考慮した $H_{\infty}$ 制御パワーアシスト車いすの開発*
}

\author{
三好 孝 典*1, 小笠原 慎一*2 \\ 北川秀夫*3, 寺 嶋一彦*1
}

\section{Development of Power-Assisted Wheelchair with $H_{\infty}$ Control to Maintain Robustness Against Load Uncertainty}

\author{
Takanori MIYOSHI*4, Shin'ichi OGASAWARA, \\ Hideo KITAGAWA and Kazuhiko TERASHIMA \\ ${ }^{* 4}$ Production Systems Engineering, Toyohashi University of Technology, \\ 1-1 Hibarigaoka, Tempaku-cho, Toyohashi-shi, Aichi, 441-8580 Japan
}

\begin{abstract}
In this paper, a power-assisted wheelchair to support helpers is presented. The model reference control system is proposed such that the wheelchair comfortably moves at the ideal speed with helper's weak force, and $\mathrm{H}$ infinity controller is implemented in order to highly maintain the control quality regardless of the disturbance such as the variation of a passenger's mass or the slope of the road. The effectiveness of the proposed system is validated through various experiments such as the comparison with the PI controller, change of patient, the up- and down-slope, and the rotary motion.
\end{abstract}

Key Words : Optimal Control, Maneuverability, Medical and Welfare Assistance, Robust Control, Power Assist

\section{1. 緒言}

現在，日本においては超高齢化が急速に進んでおり， 65 歳以上の人口の総人口に占める割合は 2013 年には $25 \%$ 超え, 2033 年には $1 / 3$ を超えると見込まれてい $ろ^{(1)}$. このような少子高齢化社会の到来に伴い, 介護 支援を目的とした新しいシステムの研究開発が盛んに 行われている.しかしながら, 高齢者を支援する機器 には, より多くの人々がより便利に使えるように安全 性や使いやすさなどが求められる. そのためには誰も が自分の思い通りに扱えるよう, 車いすにも知的機能 が求められる. そこで本研究では, 少子超高齢化社会 になるにつれ増加するであろう老老介護を想定し, 力 の弱い高齢者が使いやすいパワーアシスト介助型車い すの研究を行う.

パワーアシストを用いた介助型電動車いすは, 既に いくつかが商品化されている. ヤマハ発動機のタウ ニィーパス ${ }^{(2)}$ は, 介助者の操作力を手押しハンドル部 分で測定し, パワーアシストを行う.アシストの効果

* 原稿受付 2007 年 6 月 25 日.

*1 正員, 豊橋技術科学大学工学部(画441-8580 豊橋市天伯町 雲雀ヶ丘 1-1).

*2 大日本スクリーン製造(株) (- 602-8585 京都市上京区堀川 通寺之内上る 4 丁目天神北町 1-1).

*3 正員, 岐皁工業高等専門学校(画501-0495 本单市上真桑 2236-2).

E-mail : miyoshi@syscon.pse.tut.ac.jp
もハンドル部分のダイヤルによって段階的に調整可能 となっている. ナブテスコより発売されているアシス トホイール (3)も, やはり介助者用のハンドルに力検出 センサを付けており, 左右に加わる操作力からそれぞ れのモータパワーを決定する. しかしながら，いずれ も操作力に比例した補助動力を働かせているために, 路面の角度, 搭乗者の重量, 車輪の空気圧に依存する 転がり抵抗などが増加すると, 必要な操作力が増加す る, すなわち, 負荷変動の影響によって操作性が変化 するという問題点を有している. 誰でもが使いやすい 車い寸としては, 路面状況や搭乗者の体重に依存する ことなく, 常に同一の操作力に対して同一の操作結果, すなわち同一の速度が望まれる.

パワーアシスト車いすの基本構成は, 他のパワーア シスト機器と同様, 検出された操作力から駆動力を増 幅してプラントに与える力制御型と，操作力からしか るべき位置を目標値として生成し制御系に指令する位 置制御型に分けられる ${ }^{(4)}$. ただし，車いすにおいては 位置ではなく速度が制御されるが, 微積分の関係であ るので本質的には同一のものである.

力制御型のパワーアシスト車いすあるいは自転車に おいては, 路面状況などに対する操作性の変化の問題 を解決する手法として, 外乱推定オブザーバを用いる 方法が一般的である. 藪下らは自転車の走行抵抗を外 
乱とみなし，外乱推定オブザーバによって走行抵抗の 推定と補償を行って操作性の改善を行い(5), 関らも車 いすの左右輪にかかる外乱をオブザーバによって推定 し, 直進走行の性能改善に成功している( ${ }^{(6)}$ (7). さらに, 開田らは外乱推定オブザーバから人の操作力を推定し, センサレスのパワーアシストを実現している( ${ }^{(8)}$ セしか しながら, 体重の軽い子供, 重量者, さらに空席など, 搭乗者の状況が大きく変化する車いすでは，モデルに 依存するオブザーバよりも，むしろロバスト制御によ る外乱やモデル化誤差に対する低感度化の方向が望ま しいと考えられる. 実際, 上述の論文においては, 搭 乗者が交代した場合の性能の変化については言及して いない.

また, 力制御型では下り坂などで車いすが自重で動 いてしまう, などの問題点が指摘されている ${ }^{(9)}$. 渋谷 らにより電磁制動を用いた解決法が提案されているも のの ${ }^{(10)}$, 車いすを完全に停止させるものではなく, ま た, パワーアシストと電磁制動の併用は困難であると 考えられる。一方, 本研究で取りあげる位置 (速度) 制御型では下り坂であっても操作力が入力されない限 り車いすは運動せず，この問題は生じ無い.

位置（速度）制御型のパワーアシスト車いすとして は, 垣本らによってモデル規範型が提案されており ${ }^{(11)}$, 検出した力から車いすが運動すべき速度を演算し, PI 制御器によって速度制御を行っている.この手法では, ある程度の外乱抑制能力は期待できるものの, コント ローラの高性能化による, さらなる操作性の向上の余 地が残されている. また, 搭乗者が変化した場合や旋 回, 坂道での評価が行われていない.

著者らのグループでは，これまで病院などの狭所にお いて優れた機動性を有する全方向移動車いす（OMW） を開発している ${ }^{(12)(13)}$. このうち文献 [12] では 6 軸力 覚センサで介助者が加えた操作力を測定し, 介助者 がどのような方向に進みたいのかをファジィ推論にて 推測し，思い通りの方向へ車いすを進行させる制御を 行っている.また，文献 [13] では搭乗者の乗り心地を 考慮した制御を行っている.しかしながら，これらは 施設内のインフラストラクチャとの位置づけで開発を 行っており，本研究のように個人所有を想定した車い すのコストには収まらない.

海外では，車いすのパワーアシストに関する研究は ほとんど見られないが，車いすのモデリングに関する 研究は多く行われている. Cooper は競技用車い寸の 運動特性を解析するため自走型車いすのモデル式を導 出し ${ }^{(14)(15)}$, 操作力が加わった際の車いすの挙動を詳 しく解析している. 当該モデルは本研究においても用
いられる。

以上を踏まえて本研究では, パワーアシスト介助型 電動車いすを対象に, 基本制御構成は垣本らの手法に 従うものの，コントローラをCooper らのモデルをノ ミナルモデルとした $H_{\infty}$ 制御に変更し, 路面状況や搭 乗者の体重に影響されにくい安定な制御系の実現を試 みる. さらに, 搭乗者の変化, および坂道や旋回にお ける評価を実験によって行い，有効性を確認する。こ れにより, 誰が搭乗しても, どのような状況でも同一 の操作感を有するシステムを実現する. さらに, 実用 化も考慮して低コストの実現をはかる。

なお，本論文中「負荷変動」とは，搭乗者の体重の 変動, 道路角度がもたらす重力の影響の変化, および 車輪と路面間の転がり抵抗等を含めた外乱の変動を総 称して言う.

\section{2. 実験機のモデリングとパラメータ同定}

$2 \cdot 1$ 実験機の構成本研究では, 目的の 1 つで あるコスト抑制の観点から，市販されている車いすを 改造し実験機を製作した. 改造は, 介助者の操作力を 検出するための可変抵抗器を車いすの両操作部分 (八 ンドル)の各々に, また, 自動車用のパワーウインド 用モータと車輪の回転を検出するためのロータリーエ ンコーダを車いすの左右それぞれの後輪部に取り付け た. 改造後の車いすの写真, および外観図を図 1 およ び図 2 に示す.

操作力の検出は以下のような機構で行った. すなわ ち，スライド可能なハンドルと車い寸のアームの間に リニア可変抵抗器とバネを挿入し, 介助者の操作力に 比例してバネが圧縮・伸張をすることで, 可変抵抗器 の出力電圧が操作力に比例するようにした.

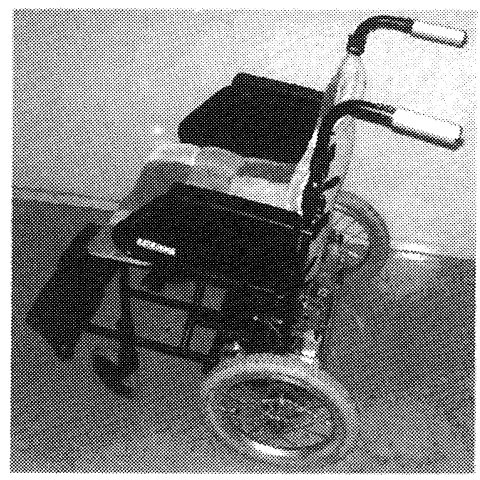

Fig. 1 Photograph of power assisted wheelchair

パワーアシスト車いすのシステム構成図を図 3 に示 す. 可変抵抗器で発生した左右それぞれの電圧は, A/D 変換器によって指令值として組み込み用マイクロコン 


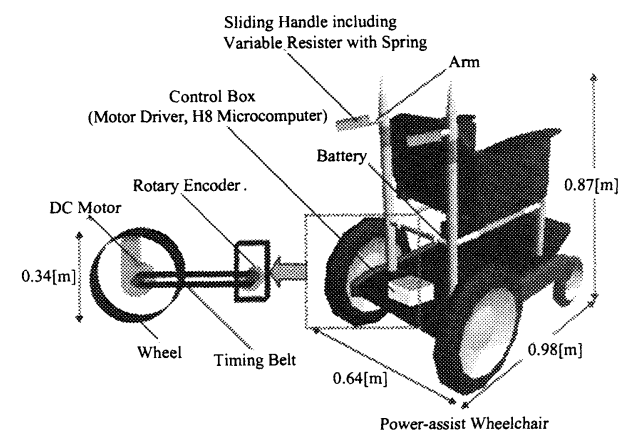

Fig. 2 Overview and mechanism of wheelchair

ピュータ (日立社製 H8) に取り込まれ，また，モータ の回転数は，マイクロコンピュータのカウンタュニッ トで計測される．ただし，当該チップにはエンコーダ 用のカウンタユニットが一つしかないため, 右車輪の 計測にはエンコーダカウント用プログラムを組み込ん だPIC/THEN2000を用いた．制御プログラムは可変抵 抗器からの指令電圧とモータの回転数を用いて左右独 立にモータドライバへの電圧を決定し, D/A 変換器に よって出力する.さらに，モータドライバは入力電圧 に比例したモ一夕駆動電圧（電圧増幅率 $\alpha$ ）をモータ に印加する.

以上, 改造に要するすべての部品は市販品, 量産品 を用いており, 改造に要する費用は市販の車いすの電 動ユニットと同程度に抑えることができる.

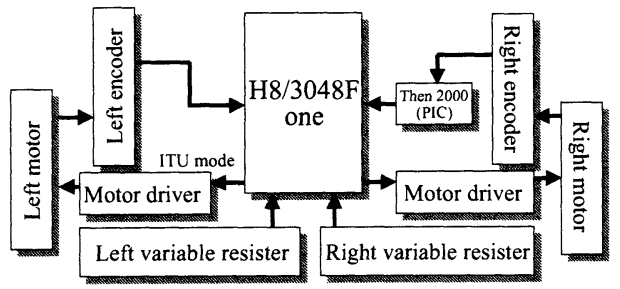

Fig. 3 Block diagram of power assisted wheelchair

$2 \cdot 2$ 車いすのモデリング＼cjkstart車いすの運動モデル としては Cooper によるモデル式 ${ }^{(14)}$ を用いる. 当該式 は自走型の競技用車いすの運動特性を解析するために 導出されたものであるが, パワーアシスト車いすに適 用するため若干の変更を加えた，すなわち，その最大 速度が競技用車いすに対して小さいために空気抵抗の 項は無視することとし，また，競技者が車いすを漕ぐ 力 (駆動力) を介助者の車いすを押す操作力に置き換え た.このとき図 4 から (1) 式を得る.

$f(t)+\frac{T_{r}(t)}{r}=M \frac{d v(t)}{d t}+c v(t)+\mu M g \cos \theta+M g \sin \theta+f_{d}$
ここで, $f(t)$ :操作力 $[\mathrm{N}], T_{r}(t)$ : モータトルク $[\mathrm{Nm}], f_{d}$ : 機械内部に存在するさまざま乾性摩擦による力の損失 $[\mathrm{N}], r$ :後輪半径 $[\mathrm{m}], M$ : 搭乗者の質量 $m_{h}$ と車いすの 質量 $m_{w}$ の合計質量 $[\mathrm{kg}$ （以降, 合計質量と称す), $c$ : 軸粘性減衰係数 $[\mathrm{N} /(\mathrm{m} / \mathrm{s})], v(t)$ : 移動速度 $[\mathrm{m} / \mathrm{s}], \mu$ :転 がり抵抗係数, $g$ :重力加速度 $\left[\mathrm{m} / \mathrm{s}^{2}\right], \theta$ :傾斜角 $[\mathrm{deg}]$ で ある. なお，(1)式の左辺第 2 項はモー夕による推進力 であり, 右辺第 3 項は転がり摩擦による力の損失, 第 4 項は坂道の勾配による力の損失である. モ一タと車 輪の慣性モーメントは搭乗者・車い寸の等価慣性モー メントに対し十分小さいので無視している.

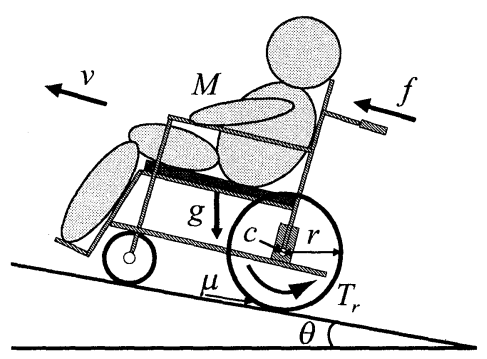

Fig. 4 Kinematics model of a wheelchair

一方, モータの電気的時定数は車いすの運動に比べ て十分早いものとすれば,

$$
T_{r}(t)=K_{t}\left(\alpha u(t)-K_{b} \frac{d \phi(t)}{d t}\right) / R_{a}
$$

であるから，(1) 式と (2) 式を組み合わせて

$$
\begin{aligned}
& f(t)+\frac{K_{t}}{R_{a} r} \alpha u(t)-\frac{K_{t} K_{b}}{R_{a} r} \frac{v(t)}{r} \\
& =M \dot{v}(t)+c v(t)+\mu M g \cos \theta+M g \sin \theta+f_{d}
\end{aligned}
$$

を得る.ここで, $K_{t}$ : トルク定数, $K_{b}$ : 逆起電力定数 $[\mathrm{V} /(\mathrm{rad} / \mathrm{s})], u(t):$ モータドライバへの入力電圧 $[\mathrm{V}], \alpha:$ モータドライバの電圧増幅率, $\phi:$ : 一の回転角 [rad], $R_{a}:$ モータの内部抵抗 (電機子抵抗) $[\Omega]$ である.

さらに, 介助者の操作力 $f$ はパワーアシストのため 十分小さく, 軸粘性減衰係数 $c$ も一般の車いすでは十 分小さいものとすると, モ一夕電圧 $u(t)[\mathrm{V}]$ から速度 $v(t)[\mathrm{m} / \mathrm{s}]$ への伝達関数は (4) 式および図 5 のように一 次遅れ系と電圧換算の等価外乱 $d$ を用いて表される. ここで $L$ はラプラス変換を表し, 線形関係が成り立つ のは外乱による不感帯の範囲外 $|u(t)-d|>0$ において である。 


$$
\left\{\begin{aligned}
V(s) & =\frac{K_{m}}{T_{m} s+1} L[u(t)-d] \\
K_{m} & =\frac{\alpha r}{K_{b}} \\
T_{m} & =M \frac{R_{a} r^{2}}{K_{t} K_{b}} \\
d & \left.=\frac{R_{a} r}{K_{t} \alpha}\left\{M g(\mu \cos \theta+\sin \theta)+f_{d}\right)\right\}
\end{aligned}\right.
$$

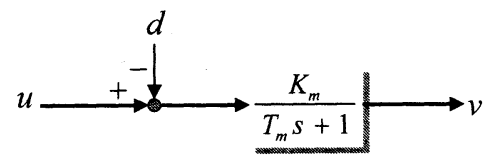

Fig. 5 Block diagram of transfer function and disturbance

\section{$2 \cdot 3$ パラメータ同定 パラメータ $K_{m}, T_{m}$ はモー} 夕等の仕様から求められるが, 実際の実験機には理論 式では十分にモデル化されていない部分があり, 特に 外乱項 $d$ には理論的には導出が困難な $\mu$ や $f_{d}$ が存 在するため, 実験に基づいてこれらのパラメータを導 出した．実験条件は，モータドライバにステップ状の 入力電圧を加えて, 速度応答より最小二乗法にて $K_{m}$, $T_{m}, d$ を求めた. 入力電圧はドライバへの入力電圧の 範囲である $0 \sim 5[\mathrm{~V}]$ の $1[\mathrm{~V}]$ 刻みとし，また，車いす の質量は $20[\mathrm{~kg}$ ], 搭乗者の質量はそれぞれ $0[\mathrm{~kg}$ （未 搭乗）, $55[\mathrm{~kg}], 70[\mathrm{~kg}], 80[\mathrm{~kg}]$ （すなわち合計質量 $M$ は, $20[\mathrm{~kg}], 75[\mathrm{~kg}], 90[\mathrm{~kg}], 100[\mathrm{~kg}])$ の各質量で同定 した.

各質量による同定結果とその回帰直線を図 6 に示す. なお，一種の体重におけるプロット点はそれぞれ 24 回の実験の平均值である. $K_{m}$ は (4) 式より, 理論的に
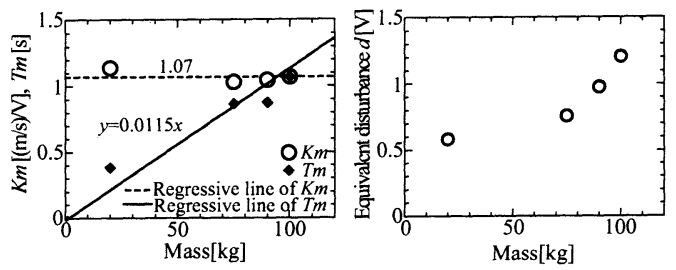

Fig. 6 Identification of parameter $K_{m}, T_{m}$, and disturbance $d$

は搭乗者の質量には依存せず一定值であることから， 同定值の平均值を採用し (点線)， $T_{m}$ は同じく(4) 式 より, 合計質量 $M$ に比例することから実線の回帰直線 を採用する. したがって, 後述の設計, およびシミュ レーションにおいては, ノミナルプラントとして $M$ に
依存する (5) 式を採用する.

$$
\left\{\begin{array}{l}
P_{M}(s)=\frac{K_{m}}{T_{m} s+1} \\
K_{m}=1.07 \\
T_{m}=0.0115 M
\end{array}\right.
$$

$d$ に関しては質量が小さい場合，一定値に収束してい るように見える.これは質量が小さい場合 $f_{d}$ の項が 支配的であるのに対し，質量の増加に伴って $M$ の項 の効果が現れるためと考えられる。

\section{3. パワーアシストシステムの構築}

本パワーアシスト制御系の指標として，以下の 4 つ を考える.

1. 介助者が「平坦な路面上で軽量な車いすを押して いる」という感覚で操作できること

2. 負荷変動が生じても, 操作力の変動が少ないこと

3. 搭乗者の質量に関わらず制御系が安定であること

4. 回転や坂道でも介助者の意図どおりの操作ができ ること

指標 1.を実現するために, 本制御系では介助者が操 作を行う際に思い描く理想の速度応答を示すモデルを 規範モデル (reference model) として制御系の前段に配 置し，プラントが規範モデルの速度指令に追従するよ うに制御を行う。図 7 に制御系のブロック図を示す。

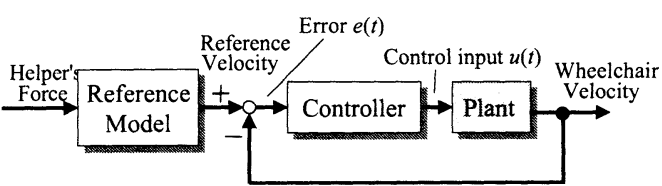

Fig. 7 Block diagram of power assisted control system

また，指標 2., 3., 4. を実現するために, $H_{\infty}$ 制御を 用いる.

3.1 指標 1 の実現 : 規範モデルの構築 規範モデ ルの構築のため，平坦路面において搭乗者がいない状 態 $(M=20[\mathrm{~kg}])$ で車いすを操作する実験を行った．ま た，比較のために $80[\mathrm{~kg}]$ の搭乗者 $(M=100[\mathrm{~kg}])$ につい ても実験を行った. 実験は, 3 人の被験者にパワーア シストのない車いすを 20 秒間操作してもらい，その 操作力と車い寸の速度を測定した。搭乗者がいない状 態での 3 人の車いすの速度応答を図 8 に, うち一人の 搭乗者の有無による相違を図 9 に示す. 三人とも車い すの速度の立ち上がりは同様の傾向を示し，また，定 常速度は 2 3[km/h] の範囲であることがわかる。こ れらの結果から，搭乗者がいない場合の操作力 $F[\mathrm{~N}]$ と速度応答 $V_{m}[\mathrm{~km} / \mathrm{h}]$ の関係を表現する式として,

$$
V_{m}(s)=\frac{0.51}{0.7 s+1} F(s)
$$


を規範モデルとして採用した. モデルの確認のため, 図 9 における搭乗者 $0[\mathrm{~kg}]$ の時の操作力の平均値 4.189[N] を(6) 式にステップで入力した時のグラフを図 8 に重 ねて示す．同様の応答が得られていることから規範モ デルの妥当性が確認できる.

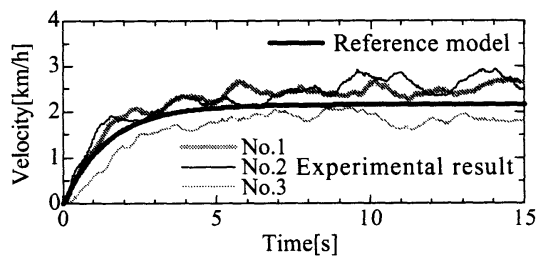

Fig. 8 The validity check of the reference model

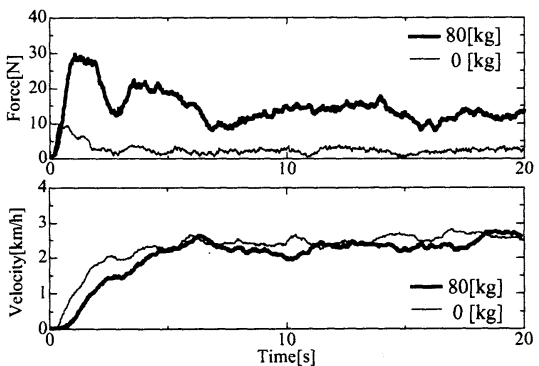

Fig. 9 Experimental results of weelchair without power-assist

なお，図 9 から，搭乗者 $0[\mathrm{~kg}]$ と $80[\mathrm{~kg}]$ では定常状 態ではほぼ同じ速度を出しているにもかかわらず加速 の立ち上がりが異なることや， $80[\mathrm{~kg}]$ 場合の加速時に は30[N] 近くの力を要しており, 高齢者が操作する場 合には負担になるであろうことが確認できる.

3.2 指標 2,3,4 の実現 : $H_{\infty}$ 制御コントローラの設 計＼cjkstart規範モデルの応答にシステムを追従させるため には，フィードバック制御系が必要であるが，特に， 搭乗者の質量の変化や路面の傾斜角の変動に対して操 作性の変化を小さくし，かつシステムを安定化するた め, 本研究では $H_{\infty}$ ロバストコントローラを採用する. 一般化プラントは, 搭乗者の質量変動によるプラント の乗法的変動に対する重み $W_{R}$, 制御対象の入力端に 加わる等価外乱の影響を抑制する重み $W_{M}$, 問題を標 準 $H_{\infty}$ 問題に帰着させるための重み $W_{N}$ を考慮して, 図 10 のように構成した。ここで $P$ はノミナルプラン ト， $K$ はコントローラである.

本来求めるべき制御仕様は，外乱に対するプラント の出力（速度）の変動を抑制するために $w_{1}$ から $z_{1}$ の のノルムが最小になること，かつ，ロバスト安定性の 確保のために $w_{1}$ から $z_{2}$ までの $H_{\infty}$ ノルムを 1 末満に することであり，(7) 式となる.しかしながら，その
ままでは非標準 $H_{\infty}$ 問題になるため, 問題を標準 $H_{\infty}$ 問題に帰着させるよう, $D_{12}$ 行のフルランク性を満た すための仮想的な観測ノイズ $w_{2}$ を導入し，(7) 式の十 分条件である図 10 の混合感度問題を最小化するコン トローラを求めた。 なお, 重み $W_{N}$ は今回 1 とした.

$$
\begin{aligned}
& \text { minimize } \gamma \\
& \text { subject to }\left\|W_{M} \frac{P}{1+P K}\right\|_{\infty}<\gamma,\left\|W_{R} \frac{P K}{1+P K}\right\|_{\infty}<1
\end{aligned}
$$

(7) 式の制約条件の第一式は搭乗者の質量変動や傾斜 角の変動による速度の変化を抑制し，第二式は搭乗者 の質量変動によってもシステムが不安定にならないこ とを意味する。

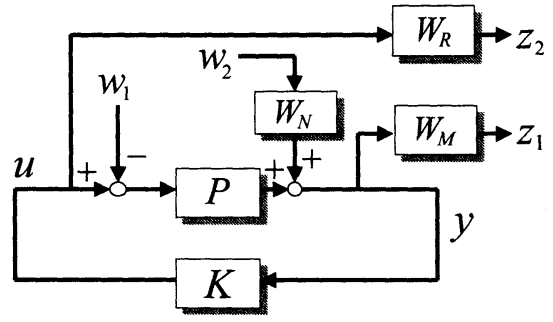

Fig. 10 Generalized plant of control system

$W_{R}$ の決定に関して，ノミナルプラント $P(s)$ に対す る乗法的変動を $\Delta_{m}(s)$ としたとき, システムの乗法的 変動分を考慮したプラント $\tilde{P}(s)$ は

$$
\tilde{P}(s)=P(s)\left(1+\Delta_{m}(s)\right)
$$

で与えられる.ノミナルプラント $P(s)$ として病院に おける患者の平均質量である $55[\mathrm{~kg}]$ のモデル式 (9) を 選定したときの，搭乗者の質量が $0[\mathrm{~kg}] \sim 80[\mathrm{~kg}]$ に変 化したときの乗法変動 $\Delta_{m}(s)$ の周波数特性を図 11 に 示す. いずれもモデル式のパラメータは前章で同定し た（5) 式を用いている．ロバスト安定性を確保するた めには，(10) 式を満たすものとして図 11 に示す $W_{R}$ を 決定した。

$$
\begin{aligned}
& P(s)=\frac{1.03}{0.865 s+1} \\
& \left|\Delta_{m}(s)\right| \leq\left|W_{R}(s)\right|
\end{aligned}
$$

$W_{M}$ の決定に関して，外乱は搭乗者の質量変動や路 面の傾斜など低周波領域が支配的であるため，低周波 領域で高ゲインでかつリファレンスに対するサーボ特 性を持たせるよう，原点に近い極を持った 1 次遅れを 用いて近似的に積分器特性を表現させた．近似的にし ているのは， $H_{\infty}$ 標準問題では極が原点にあるものは 解けないためである，設計した重み $W_{R}, W_{M}$ を(11) 式，および図 11 に示す.

$$
W_{R}=\frac{1.366 s+0.0001}{s+2.0}, \quad W_{M}=\frac{2.3}{s+0.0001}
$$




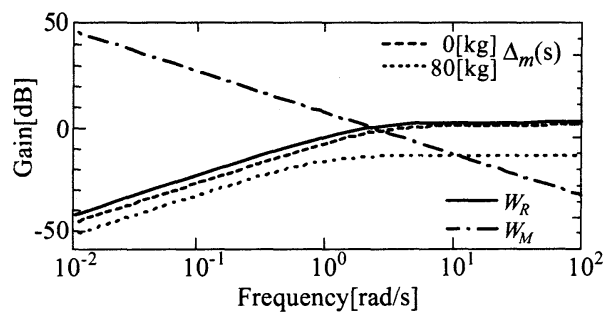

Fig. 11 Multiplicative uncertainty, and Weight function $W_{R}$ and $W_{M}$

以上の $P(s), W_{R}(s), W_{M}(s), W_{N}$ を用いて, Matlab の 関数 Hinfric により $K(s)$ を求めた。結果を (12) 式に, ゲイン特性を図 12(a)の太線に示す. 細線と (b) に関 しては後述する。

$$
K(s)=\frac{69.0601 s^{2}+235.0262 s+193.8122}{s^{3}+57.4265 s^{2}+106.2601 s+0.0106}
$$

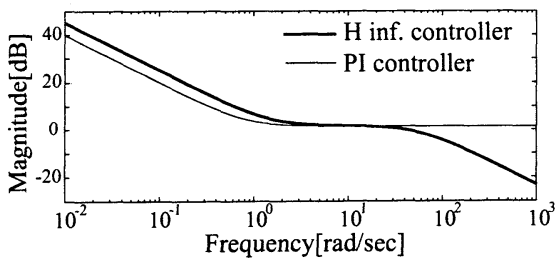

(a) Gain diagram of $\mathrm{H}$ infinity and PI controller

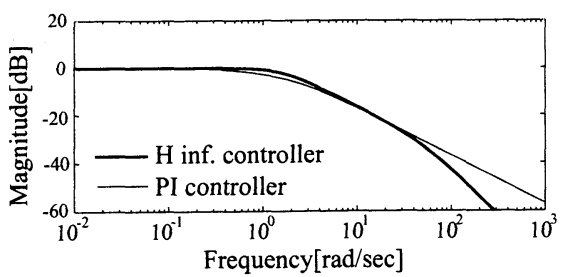

(b) Gain diagram of complementary sensitivity functions

Fig. 12 Comparison of frequency characteristics between $H_{\infty}$ and PI control

3.3 比較のための PI コントローラの設計 本 $H_{\infty}$ コントローラの有効性を証明するために, 比較対 象として PI コントローラを設計した. PI コントロー ラの式は図 7 の記号を用いて,

$$
u(t)=K_{p} e(t)+K_{i} \int_{0}^{t} e(\tau) d \tau
$$

で表される.ここで $K_{p}$ は比例ゲイン,$K_{i}$ は積分ゲイ ンである. 比較対象としての十分な能力を担保するた
めに, $K_{p}, K_{i}$ の值は以下で述べるシンプレックス法を 用いた最適化手法 ${ }^{(16)}$ とともに, 実験上, 車椅子が安定 に動作するパラメータを導出した.

すなわち, 以下のペナルティー項つきの最適化問題 を解く.

$$
\min J=J_{t}+J_{P}
$$

ここで, $J_{t}$ は主たる評価関数で, 本 PI コントローラに よるクローズループの整定時間である.ここで言う整 定時間とは, $6[\mathrm{~N}]$ のステップ状の操作力を加えた場合 に, リファレンス速度と実機の速度の差が車いすの定 常速度の $+/-10 \%(+/-0.3[\mathrm{~km} / \mathrm{h}])$ に到達した時間と定義 する. 一方, $J_{P}$ はペナルティー項で, 制約を満たす場 合は $J_{P}=0$, 満たさない場合は $J_{P}=10^{10}$ とする.こ こで言う制約とは, 図 9 のプラントへの入力電圧が飽 和電圧の $5[\mathrm{~V}]$ に到達することを言う。これらの条件 は,ノミナルプラントにおいて, 自然な歩行運動の際 に飽和によるワインドアップが起きないことを考慮し て決定した.

シンプレックス法を用いるにあたって, 鏡像係数 $\alpha=1.0$, 収縮係数 $\beta=0.5$, 拡散係数 $\gamma=2.0$ とし, さまざまな初期值による試行錯誤を繰り返した結果， 制約下の最短時間搬送を実現する最適ゲインとして $K_{p}=1.2, K_{i}=1.0$ を決定した. また，このときのコン トローラのゲイン特性を図 12 の細線に示す.

\section{4. 制御実験結果および指標の検証}

\section{1 指標 1 の検証 : 軽量な車いすの操作感の実現} 得られた $H_{\infty}$ コントローラを用いて,「軽量な車いすと 同様の操作感」が実現できているかを検証した. 80[kg] の搭乗者を乗せて, 自然な歩行速度で車いすを前方向 に進めた際の操作力と車いすの速度の測定結果を図 13 に示す.太破線はパワーアシストを用いた場合, 中太 実線は用いない場合である，また，パワーアシストを 用いない未搭乗者の場合も細実線に示す.

パワーアシストを用いない $80[\mathrm{~kg}]$ の場合, 速度の 立ち上がりも遅く, 際立って大きな操作力を要する一 方, パワーアシスト有りの $80[\mathrm{~kg}]$ では, パワーアシ ストの無い未搭乗者に比べ若干劣るものの, 立ち上が りも早く, 小さな操作力に抑えられている. 搭乗者質 量 80[kg] の 7[m] 走行における介助者の仕事量は, パ ワーアシスト有りで 84.8[J], パワーアシストなしで 234.7[J] と，本コントローラによりおよそ1/3に軽減 できた.

4.2 指標 2,3 の検証 : 負荷変動に対するロバスト性 まず, $H_{\infty}$ コントローラを用いて, 平坦な路面上を搭 乗者無しと搭乗者 $80[\mathrm{~kg}]$ で，自然な歩行速度で車いす 

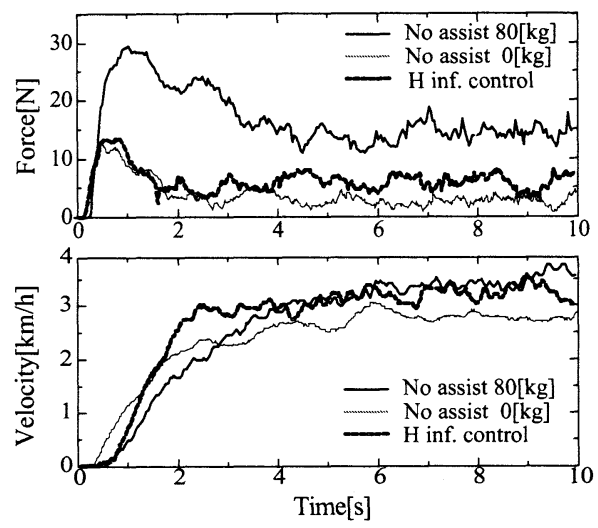

Fig. 13 Comparison between $H_{\infty}$ control and "without" power-assist

を前方向に進めて実験を行った．それぞれの操作力と 速度，モータドライバへの電圧の測定結果を図 14 に 示す，なお，人が実際に車いすを押す実験は操作力を 再現することが困難であるため, 操作力を $6[\mathrm{~N}]$ の一 定の力でステップ入力するよう, 規範モデルの前段で マイクロコンピュータの処理を施した．破線は規範モ デルからの速度指令の出力, 実線が実際の車いすの速 度である.いずれの質量においても安定した制御が行 われていることがわかる，また，搭乗者の質量によら ず $2 つ の$ 速度応答がほぼ一致しており, 負荷変動に対 してロバストであると判断できる．電圧のグラフから も質量が大きい場合に，よりアシスト力を強めるよう 適切な制御が行われていることが読み取れる.

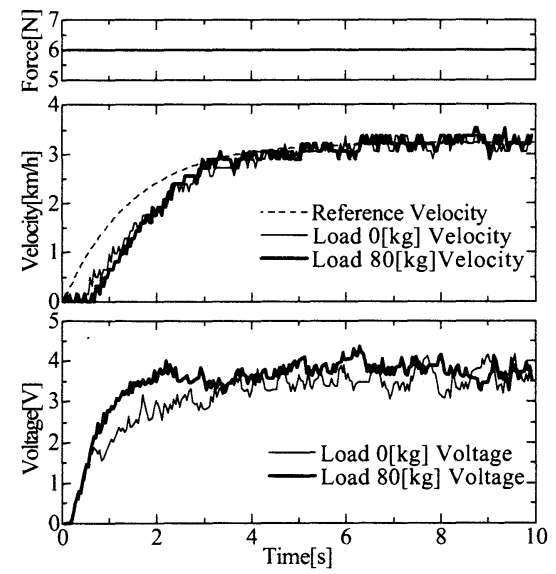

Fig. 14 Experimental results of robust controller according to mass of subject
4.3 PI コントローラとの比較 本 $H_{\infty}$ コントロー ラが，従来の古典制御よりも負荷変動に対するロバス 卜性を有していることを明らかにするために，前章で 述べた PI コントローラとの比較を行った．第 4.2 節 と同一の実験を行った結果を図 15 に示す. PI コント ローラでは, $80[\mathrm{~kg}]$ の速度応答の立ち上がりが $0[\mathrm{~kg}]$ のそれよりも緩やかになることがわかる.すなわち， PI コントローラを用いた場合, 介助者は搭乗者の質量 に応じて異なる操作感を覚える. また, 図 14 と比較 すれば明らかなように, PI 制御の電圧の立ち上がりは $H_{\infty}$ コントローラのそれに比べ遅く, 速度の立ち上が りも緩やかとなっている.

本 $H_{\infty}$ コントローラが，負荷変動に対して高いロバ スト性を有している要因としては, 図 12(a)により明ら かなように，低周波領域で開ループゲインが, 約 $5[\mathrm{~dB}]$ ほど大きいことが上げられる，また，同図 (b) の相補 感度関数のゲイン線図の比較でも明らかなように, $H_{\infty}$ コントローラの方がサーボ帯域が広く, 速度の立ち上 がりが早いことが確認できる.
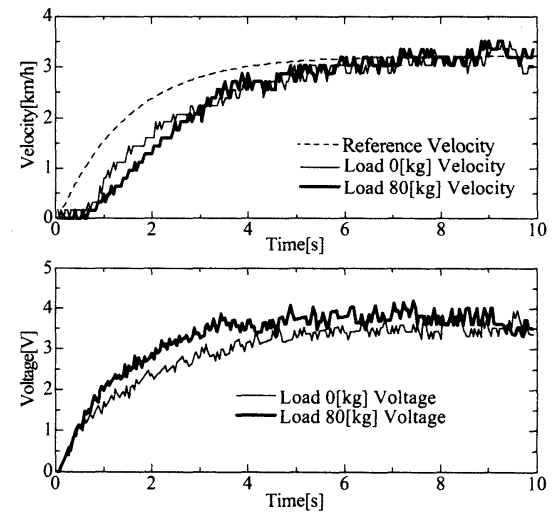

Fig. 15 Experimental results of PI controller according to mass of subject

4.4 指標 2, 4 の検証 : 坂道におけるロバスト性 (4) 式に示されるように, 負荷変動には路面の傾斜角 度も含まれる. そこで, 傾斜角度における操作性の口 バスト性を検証した．搭乗者は $80[\mathrm{~kg}]$ とし，+/-2。の 傾斜を登坂，降坂したときの操作力と車いすの速度の グラフを図 16 に示す. 速度の立ち上がりに相違は見 られるが，最大操作力や定常的な特性はほぼ一致して いる.これは，設計時にコントローラに積分特性を持 たせ, $0.1[\mathrm{rad} / \mathrm{s}]$ 以下の低周波においてゲインを十分 大きくした効果である（図 12）。登坂時において，操 作力を加えてから 1 秒後に速度が立ち上がる理由は, モータ電圧が坂による重力に拮抗するまでに要する時 
間である.なお, パワーアシストを用いない場合は， 図 17 に示すように, 登坂時は 50[N] 以上の操作力が 要求され, 降坂時は操作力がほぼ 0 にもかかわらず車 いすが加速するという現象が見られた.

以上, $4.2,4.3,4.4$ 節の検証により，本 $H_{\infty}$ コント ローラは坂道や搭乗者の質量変化などの負荷変動に対 して操作性の変化が少なく, 介助者の意図どおりの操 作が可能であると判断できる.

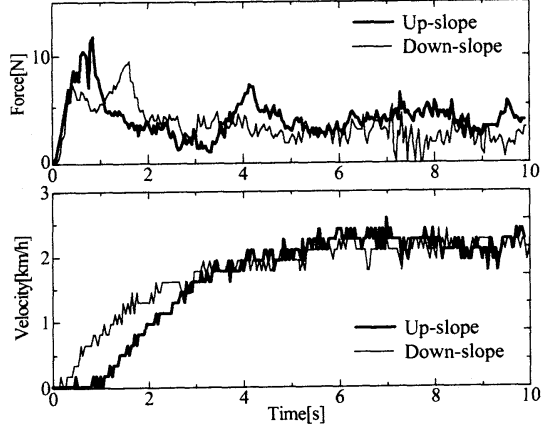

Fig. 16 Experimental results with robust controller according to slope
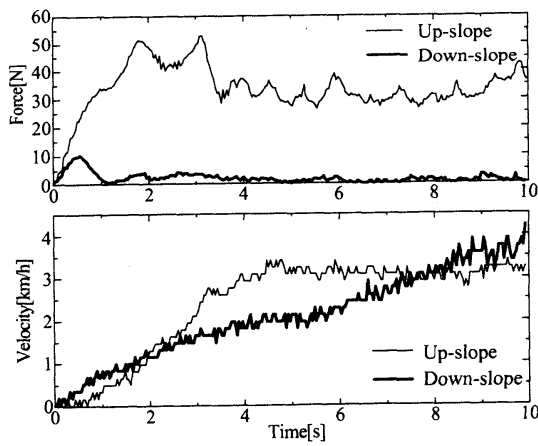

Fig. 17 Experimental results without power-assist according to slope

4.5 指標 4 の検証 : 回転における操作性 回転 動作も車いすにおいてよく用いられる動作である. 本 $H_{\infty}$ コントローラによっても回転時の操作性が確保さ れていることを実証するために，比較実験を行った. 車いすの中心における回転半径が $0.30[\mathrm{~m}]$ となる円を 目標経路とし，目標経路にできるだけ一致するよう, 約 $10[\mathrm{~s}]$ で原点から車いすを回転させた場合の軌跡を， $H_{\infty}$ コントローラによるパワーアシスト有りと無しの 場合で比較した．JIS では半径 $0.9[\mathrm{~m}]$ の円での試験が 指定されているが(17)，パワーアシストによって手動車 いすより操作性が向上することを示すため, より小半
径での測定を試みた．搭乗者は $80[\mathrm{~kg}]$ である，比較実 験の結果を図 18 に示す．図の (a) が右回転の場合，(b) が左回転の場合である。それぞれにおいて，左上図が 操作力の変化を，左下図が車いすの速度を，右図が回 転軌跡を表す．左右いずれの回転においてもパワーア シストを用いた方が操作力および経路誤差が小さく， 良好な操作性が確保できていることが確認できる。こ れは，小半径での回転の場合，回転のひねりを考慮し た強い操作力と決め細やかな操縦が必要になるが，パ ワーアシストによって操作力が軽減され，操縦に専念 できるためと考えられる.
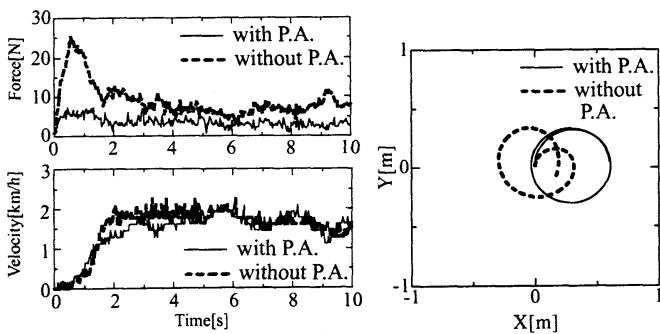

(a) $\mathrm{cw}$
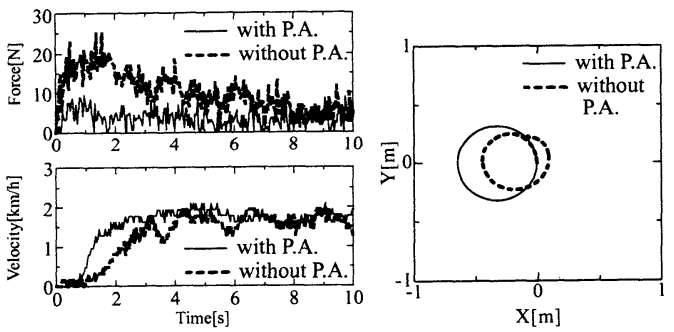

(b) $\mathrm{ccw}$

Fig. 18 Experimental results of rotation compared between with and without power-assist

\section{5. 結言}

本論文では，モータの電気的特性を考慮しつつ，車 いすの運動方程式から本パワーアシスト車いすのモデ ルの導出を行い，搭乗者の質量の変動や路面の角度が 運動に及ぼす影響を定式化した。ささらに，パワーアシ スト車いすの実験機を製作し，モデルの伝達関数や外 乱のパラメータ同定を行った。制御設計においては, 4 つの指標，すなわち 1. 平坦な路面上で軽量な車い すを押している感覚の実現, 2. 負荷変動が生じても, 操作力の変動が少ないこと，3. 搭乗者の質量に関わら ず制御系が安定であること, 4. 回転や坂道でも介助者 の意図どおりの操作ができること，を設け，これらを 満足させるために $H_{\infty}$ 制御系を構築した. さらに，搭 乗者質量の変動および路面状況の変化に対してロバス 
トな制御が達成されていることを, 搭乗者の有無, PI 制御との比較, 坂道搬送, 回転操作などの実験を通じ て確認し，本制御系の有効性を示した.

\section{文献}

(1) Population Projections ed., National Institute of Population and Social Security Research, (2006), p.3, Population Projections

(2) http://www.yamaha-motor.co.jp/product/wheelchair /complete/townypas/index.html,(2007)

(3) http://welfare.nabtesco.com/as.htm,(2007)

(4) Seki, H., Iso, M., Hori, Y., How to design force sensorless power assist robot considering environmental characteristics -position control based or force control based, Proc. of IEEE 28th Annual Conference of the Industrial Electronics Society (IECON'02), Vol.3, (2002), pp.2255-2260

(5) Yabushita, H., Hirata, Y., Kosuge, K., Control of Power Assisted Cycle with Adjustable Apparent Drag Force, Trans. of the Japan Society of Mechanical Engineers, Series C, Vol.69, No.680(2003), pp.1031-1036

(6) Seki, H., Sugimoto, T., Tadakuma, S., Novel Straight Road Driving Control of Power Assisted Wheelchair Based on Disturbance Estimation of Right and Left Wheels, Trans. of the Institute of Electrical Engineers of Japan, Series D, Vol.126, No.6(2006), pp.764-770

(7) Seki, H., Sugimoto, T., Tadakuma, S., Straight and Circular Road Driving Control for Power Assisted Wheelchair, Proc. of 23th Annual Conference of Robotics Society of Japan, (2005), 3H31

(8) Kaida, Y., Murakami, T., An Approach to Sensorless Detection of Human Input Torque and Its Application to Power Assist Motion in Electric Wheelchair, Trans. of the Institute of Electrical Engineers of Japan, Series D, Vol.126, No.2(2006), pp.137-142

(9) Kakimoto, A., Control Technology of Mobility Aids for Elder Persons(in Japanese), J. of the Society of Instrument and Control Engineers, Vol.40, No.5(2001), pp.357-362
(10) Shibuya, K., Yoshimatsu, H., Iwamoto, T., Development of power assisted wheel chair that can change assisting rate, JSME Conf. on Robotics and Mechatronics, (2004), 1P1-H-62

(11) Kakimoto, A., Matsuda, H., Sekiguchi, Y., Development of Power-Assisted Attendant-Propelled Wheelchair, $\boldsymbol{J}$. of the Japan Society for Precision Engineering, Vol.65, No.8(1999), pp.1126-1130

(12) Kitagawa, H., Nishizaka, S., Miyoshi, T., Terashima, K., Development of Power Assist System for Omni-directional Transport Wheelchair, J. of the Robotics Society of Japan, Vol.23, No.3(2005), pp.321-329

(13) Kitagawa, H., Beppu, T., Ohno, Y., Miyoshi, T., Terashima, K., Motion Control of Omni-directional Mobile Wheelchair Considering User's Comfort, J. of the Robotics Society of Japan, Vol.22, No.7(2004), pp.933939

(14) Cooper, R. A., A Systems Approach to the Modeling of Racing Wheelchair Propulsion, J. Rehabil. Res. Dev, Vol.27, No.2(1990), pp151-162

(15) Cooper, R. A., A Force/Energy Optimization Model for Wheelchair Athletics, IEEE Trans. on systems man and cybernetics, Vol.20, No.2(1990), pp444-449

(16) Yamamoto, Y. and Koyama, T.(Translator), Kowalic, J. and Osborne, M. R.(Author), Methods for Unconstrained Optimization Problems, (1970), p.27-33, Baifukan

(17) Japanese Industrial Standards, T-9203, (2006) 